\title{
URBAN PUBLIC SPACES: UNDERSTANDING THROUGH THE PRISM OF FOREIGN DISCOURSE
}

\author{
'Natalia MEZENTSEVA, ${ }^{2}$ Maria PALCHUK \\ Taras Shevchenko National University of Kyiv, Ukraine \\ 'provotarnat@ukr.net, ${ }^{2}$ marialookhere@gmail.com
}

\begin{abstract}
The modern city focuses the crossing of complicated, ambiguous, multidimensional social processes. They are manifested in multiple aspects of it functioning from different sides, such as population (person, community, and dwellers), politics, economics, and have got space-time peculiarities. To some extent public space is a unique element in terms of city functioning and urban development, where simultaneously accumulated results of all processes of urban transformation. In 1990s, urban public spaces as relatively new field of study attracted the attention of sociologists, urbanists and architects. Since, in foreign publications were presented considerable diversity of theoretical, methodological and applied approaches to understanding and exploring public spaces, their transformation. Studies have confirmed that public spaces are not placelessness phenomenon, but their development is drived by local traditions and culture, available resources, forms of regulation. However, all of them are characterized by some common functions, features, transformations and their consequences. Therefore, to understand the nature of public spaces and to determine directions of their investigation from human geographer's point of view we need analyze contemporary conceptualization in foreign discourse, acquaint the results of their research in post-socialist countries, where functions of public space during long time were largely controlled and restricted. This article provides an overview of the foreign concepts of urban public space in order to highlight the main approaches, trends and tasks of studying of urban public spaces in Ukraine based on human geography vision.
\end{abstract}

Key words: public space, city, urban public space, spatial analysis, transformation.

DOI: https://doi.org/10.17721/2413-7154/2016.76.19-26

UDC: 911.3

\section{ПУБЛІЧНІ ПРОСТОРИ МІСТ: ОСМИСЛЕННЯ ЧЕРЕЗ ПРИЗМУ ЗАРУБІЖНОГО ДИСКУРСУ}

\author{
'Наталія МЕЗЕНЦЕВА, ${ }^{2}$ Марія ПАЛЬЧУК \\ Київський національний університет імені Тараса Шевченка, Україна \\ 'provotarnat@ukr.net,2marialookhere@gmail.com
}

Резюме: Сучасне місто фокусує перетин складних, неоднозначних, багатовимірних суспільних процесів. Вони проявляються в різних аспектах його функціонування на таких зрізах як населення (особа, громада, мешканці), політика, економіка, та мають часові і просторові особливості. Певною мірою унікальним елементом з точки зору функціонування і розвитку міст, де одночасно акумулюються результати всіх процесів міських трансформацій, є публічний простір. Як порівняно новий об'єкт дослідження міські публічні простори привернули до себе увагу соціологів, урбаністів та архітекторів 3 90-х років XX ст. 3 того часу у зарубіжних публікаціях було представлено значне розмаїття теоретичних, методичних та прикладних підходів до розуміння та вивчення публічних просторів, напрямків їх трансформацій. Дослідження підтвердили, що публічні простори не характеризуються безмісцевістю, а визначаються у своєму формуванні та функціонуванні місцевими традиціями та культурою, наявними ресурсами, формами регулювання. Водночас, всім їм притаманні певні загальні функції, властивості, трансформації та їх наслідки. Для розуміння сутності публічних просторів та визначення напрямків їх суспільно-географічного дослідження необхідно проаналізувати сучасні зарубіжні концептуальні засади, ознайомитись із результатами їх дослідження в постсоціалістичних країнах, де тривалий час функції публічних просторів були значною мірою контрольованими та обмеженими. В статті представлено огляд зарубіжних концепцій публічних просторів міст з метою виділення основних підходів, напрямів та завдань суспільно-географічних досліджень міських публічних просторів в Україні.

Ключові слова: публічний простір, місто, міський публічний простір, просторовий аналіз, трансформації.

DOI: https://doi.org/10.17721/2413-7154/2016.76.19-26

Удк: 911.3

\section{ПУБЛИЧНЫЕ ПРОСТРАНСТВА ГОРОДОВ: ОСМЫСЛЕНИЕ ЧЕРЕЗ ПРИЗМУ ЗАРУБЕЖНОГО ДИСКУРСА}

\author{
'Наталья МЕЗЕНЦЕВА, 'Мария ПАЛЬЧУК
}

Киевский начиональный университет имени Тараса Шевченко, Украчна

'provotarnat@ukr.net, ${ }^{2}$ marialookhere@gmail.com 
Резюме: Современный город фокусирует пересечение сложных, неоднозначных, многомерных социальных процессов. Они проявляются в различных аспектах его функционирования на таких срезах как население (личность, общество, жители), политика, экономика, и имеют временные и пространственные особенности. В определенной степени уникальным элементом с точки зрения функционирования и развития городов, где одновременно аккумулируются результаты всех процессов городских трансформаций, является публичное пространство. Как сравнительно новый объект исследования городские публичные пространства привлекли к себе внимание социологов, урбанистов и архитекторов в 90-х годах XX века. С тех пор в зарубежных публикациях было представлено значительное разнообразие теоретических, методических и прикладных подходов к пониманию и изучению публичных пространств, направлений их трансформаций. Исследования подтвердили, что публичные пространства не характеризуются безместностью, а определяются в своем формировании и функционировании местными традициями и культурой, имеющимися ресурсами, формами регулирования. В то же время, всем им присущи некоторые общие функции, свойства, трансформации и их последствия. Поэтому для понимания сущности публичных пространств и определения направлений их общественно-географического исследования необходимо проанализировать современные зарубежные концептуальные основы, ознакомиться с результатами их исследования в постсоциалистических странах, где долгое время функции публичных пространств были в значительной степени контролируемыми и ограниченными. В статье представлен обзор зарубежных концепций публичных пространств городов с целью выделения основных подходов, направлений и задач общественно-географических исследований городских публичных пространств в Украине.

Ключові слова: публичное пространство, город, городское публичное пространство, пространственный анализ, трансформации.

DOI: https://doi.org/10.17721/2413-7154/2016.76.19-26

УдК: 911.3

Постановка проблеми. В різні історичні періоди в містах України актуалізувалось виконання публічними просторами політичних, комунікаційних, рекреаційних функцій, функцій територіальної ідентичності та самоідентифікації. Нині для публічних просторів міст України характерні суттєві трансформації. Вони пов'язані 3 необхідністю осмислення та визначення позитивних і негативних наслідків комерціалізації та приватизації публічних просторів, їх виокремлення, «закриття», «диснейфікації», недоступності для окремих членів громади, сакралізації, зростання ролі молів, орієнтації на транспортну доступність, «європеїзації». Важливого значення при цьому набуває необхідність суспільно-географічного їх дослідження на основі сформованих зарубіжних концепцій публічних просторів міст. Саме тому виникає потреба в огляді наукової дискусії провідних вчених світу щодо витоків, сутності, ознак поняття «публічного простору», його просторового аналізу, сучасних трансформацій та динаміки 3 метою проведення суспільно-географічних досліджень міських публічних просторів в Україні.

Формулювання цілей статті. Метою написання даної роботи є огляд сучасного зарубіжного дискурсу щодо дослідження публічних просторів міст для виділення основних підходів, напрямів та завдань суспільно-географічних аспектів дослідження публічних просторів міст в Україні.

Виклад основного матеріалу. Розуміння сутності публічного простору міст пов'язане 3 тлумаченням поняття «публічного». Якщо під публічним розуміти те, що стосується держави, то публічний простір визначатиметься як простір, в межах якого забезпечується функціонування держави, виконання іiі функцій. Якщо публічним вважати те, що стосується держави та економіки, то публічні простори розуміють як простори, в межах

(C) Н. Мезенцева, М. Пальчук яких забезпечується економічна діяльність. Якщо публічне розуміти як таке, що стосується громади, громадян, то публічний простір буде простором, в межах якого громади встановлюють правила участі відповідно до моральних цінностей та соціальних очікувань. Якщо публічне - це те, що стосується комунікабельності, відкритого самовираження, то публічний простір - це простір самовираження та комунікації.

Основні акценти зарубіжних досліджень публічних просторів міст зосереджені на таких чотирьох напрямках (рис.1):

- визначення сутності поняття «публічний простір», ознак публічності;

- роль публічних просторів міст у житті громади та їх використання;

- просторовий аналіз, планувальні аспекти публічних просторів міст;

- динаміка та сучасні трансформації міських публічних просторів.

3. Ніл (Zachary Neal), систематизувавши бачення різних авторів сутності поняття «публічний простір», ознак публічності та ключових проблем, у статті «У пошуках спільного: три підходи до публічного простору» («Seeking common ground: three perspectives on public space») [17] виділив три підходи до дослідження публічних просторів: економіко-правовий, соціально-просторовий та політичний (рис. 2). Кожен із зазначених 3. Нілом підходів дає можливість висвітлити ту чи іншу сторону публічного простору. Залежно від предмету дослідження вони дають можливість визначити найпроблемніші місця функціонування конкретного публічного простору в рамках підходу.

Економіко-правовий підхід передбачає пошук відповіді на питання про те, що таке публічний простір і хто за нього платить. Перше юридичне тлумачення публічного простору було сформульоване у 1939 році в США після серії судів мера Джерсі-Сіті Ф. Гаг'ю проти Комітету з організації промислового виробництва. які підтвердили 
важливість публічних просторів у якості ключових об'єктів для діяльності. У 1983 році в США було встановило трирівневу правову концепцію публічного простору, відому як доктрину публічного форуму. Відповідно до неї, відкритий тип публічного простору повинен завжди бути відкритим для всіх. Закритий тип публічного простору включає об'єкти державної власності, які не призначені для публічного спілкування. Третій тип - це обмежений публічний простір, що включає в себе державну власність, яка не є традиційно відкритою, але яку відкрили для використання громадськістю.

3 економічної точки зору публічний простір є одним з видів суспільного блага у якості ресурсу. Таке його трактування передбачає дослідження питання необхідності публічного простору, його фінансової корисності для міста. У цьому контексті важливими є дослідження значення і ролі публічних просторів у стратегіях ревіталізації міст, їх важливості для соціально-економічного розвитку міст, зокрема ролі торговельно-розважальних центрів (молів) для економічного зростання та підвищення рівня життя жителів міст.

Соціально-просторовий niдxid основну увагу концентрує на питаннях дизайну та використання публічних просторів міст. У межах соціальнопросторового підходу до дослідження публічних просторів міст було сформовано два напрями досліджень. Перший напрямок фокусується на визначенні шляхів максимізації користі публічних просторів за рахунок їх оптимального проектування i планування. Другий напрям основну увагу приділяє соціальним функціям публічних просторів та аналізу наслідків їх функціонування як елементів міського середовища.

У межах даного підходу виділяються такі ключові положення:

- основним просторовим рівнем досліджень $\epsilon$ рівень міських вулицьь (вулиця 3 ii пейзажами, «the urban streetscape»), як найбільш публічних та найчастіше використовуваних публічних просторів у повсякденному житті міста;

\section{Сутність поняття}

та ознаки

Просторовий аналіз

та планувальні аспекти

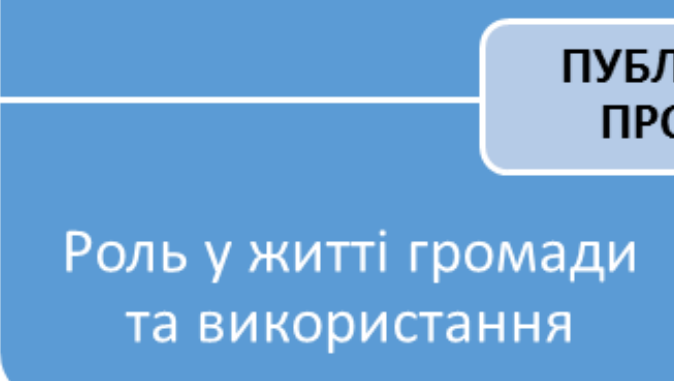

Рис. 1. Основні напрями зарубіжних досліджень публічних просторів міст

\begin{tabular}{|c|c|c|}
\hline Економіко-правовий & Соціально-просторовий & Папі тичний \\
\hline \multicolumn{3}{|c|}{ Ключові пшт ання в рамках підходу } \\
\hline $\begin{array}{c}\text { Що таке публічний } \\
\text { простір? } \\
\text { Хто за ншого платить ? }\end{array}$ & $\begin{array}{c}\text { Як виглядає публічний } \\
\text { простір? } \\
\text { Як він } \\
\text { використовується? }\end{array}$ & $\begin{array}{c}\text { Яка роль публічних } \\
\text { просторів у } \\
\text { демократичному } \\
\text { суспільстві? }\end{array}$ \\
\hline \multicolumn{3}{|c|}{ О сновні напр ямп дослідження } \\
\hline $\begin{array}{l}\text { - Трактування } \\
\text { правового статусу } \\
\text { публічного простору. } \\
\text { - Фінансовий зиск } 3 \\
\text { публічних просторів. }\end{array}$ & $\begin{array}{l}\text { - Дослідження міських } \\
\text { вулиць, як основного } \\
\text { просторового рівня. } \\
\text { - Розгляд соціальної } \\
\text { д исфункції публічного } \\
\text { простору як виклику. } \\
\text { - Еволюція публічних } \\
\text { просторів. }\end{array}$ & $\begin{array}{l}\text { - Публічний простір } \\
\text { як засіб долучення до } \\
\text { політичного процесу. } \\
\text { - Поведінка в } \\
\text { публічному просторі та } \\
\text { ії контроль. }\end{array}$ \\
\hline
\end{tabular}

Рис. 2. Підходи до дослідження публічних просторів міст за 3. Нілом 
- відносно оптимістичний погляд на публічний простір, коли соиіальна дисфункиія розглядається не як визначальна ознака простору, а як виклик, який необхідно подолати за рахунок поліпшення дизайну публічного простору;

- визнання еволюиії публічних просторів: старі форми публічних просторів можуть зникати, а натомість створюються нові, або трансформуватись 3 часом.

У рамках даного підходу проводяться ряд досліджень публічних просторів міст. Зокрема, Дж. Джакобс (Jane Jacobs) [3] досліджувала соціальні функції публічних просторів, виявляючи залежність життєздатності і безпеки окремих міських околиць від їх просторових конфігурацій, щільності та різноманітності розміщених в їх межах публічних просторів. Містобудівник К. Лінч (Kevin A. Lynch) [14] досліджував вплив просторових особливостей публічних просторів на конструювання ментальних карт, які дозволяють людям орієнтуватися і відчувати складні середовища. Урбаніст В. Вайт (William H. Whyte) [23], засновник американської організація «Project for Public Spaces», намагався емпірично довести зв'язки між формою і функцією на прикладі міських площ, а потім і інших видів відкритих публічних просторів міст.

Політичний nidxid фокусується на визначенні ролі публічних просторів в умовах демократії. Публічний простір розглядається як місие розбрату, де відбуваються процеси виключення та домінування, та як інституиія, яка зникає так само швидко, як і сама демократія.

Ключовими темами досліджень в рамках даного підходу є:

- визначення публічного простору як засобу долучення до політичного процесу. Зокрема, Ю. Габермаса (Jürgen Habermas) [2] використовував термін «публічна сфера» («public sphere») для опису абстрактної форми публічного простору, заповненого ідеями, думками, дебатами з приводу питань, що становлять суспільний (публічний) інтерес. Він вважає, що публічна сфера існує на рівні усного/ письмового обміну ідеями, дозволяє долучитись до політичного процесу через участь у дебатах. Г. Арендт (Hannah Arendt) [1] доповнила це думкою про те, що кожен може не лише прийняти участь у створені консенсусу, а й долучитись до колективної політичної дії задля досягнення спільних завдань. У концепції А. Лефевра (H. Lefebvre) «Право на місто» («Right to the city») [12] закріплено основні права громадян на доступ не тільки до фізичних публічних просторів, але i до публічної сфери політичної участі, яку такі простори роблять можливою.

- поведінка в публічному просторі міста та іiі контроль. Н. Сміт (Neil Smith), С. Лоy (Setha Low), Д. Харві (David Harvey), Д. Мітчелл (Don Mitchell), M.Девіс (Mike Davis) описують процеси комерціалізації, приватизації, занепаду публічних просторів та виключення різних соціальних груп із використання публічних просторів у неоліберальному суспільстві $[8,11,13,16]$.
Суспільно-географічні дослідження публічних просторів варто здійснювати одразу 3 позицій декількох підходів. Дослідження у межах одного підходу може бути не повним та не комплексним. Так, визначення сутності поняття «публічний простір» у межах економіко-правового та соціальнопросторового підходів є досить близькими. Проте, розуміння динаміки публічних просторів лише 3 позицій економіко-правового підходу $є$ невичерпним. Найбільш аргументованим $є$ його поєднання iз соціально-просторовим поясненням. Так само вдалим є поєднання політичного та соціальнопросторового підходів для виявлення впливу форм публічного простору на участь людей у громадянському суспільстві [17].

Вагомим напрямком зарубіжних досліджень публічних просторів є аналіз їх динаміки.

Як результат дослідження динаміки публічних просторів висловлюється ідея втрати публічних просторів («the loss of public space»), що пов'язана зі зміною способу життя мешканців міст: накопиченням сімейного або індивідуального капіталів, зростанням рівня автомобілізації міст, субурбанізацією, розвитком електронних соціальних мереж, соціальною сегрегацією. У результаті таких процесів площі сучасних міст 3 гарною транспортною доступністю стають майданчиками реалізації девелоперських проектів комерційної нерухомості, що в переважній більшості випадків фізично руйнує та спотворюе історичний вигляд міських площ. Концентрація комерційної діяльності перетворює публічні простори на міські транспортні коридори або ж парковки, окуповані автомобілями працівників та клієнтів бізнес-центрів, які утримуються за рахунок міського бюджету. Рух пішоходів по вузьких тротуарах нагадує проходження лабіринту із припаркованих машин.

P. Сеннетт (Richard Sennett) у книзі «Падіння публічної людини» («The fall of public man») [20] зауважує, що сучасне суспільство перетворило окремі вулиці та площі міст на місця транзиту, замінивши такий публічний простір на «приміське житло» («suburban living rooms»). Це, як правило, породжує наступну проблему: чим менше людей використовують публічні простори, тим менше стимулів у муніципальної влади створювати нові та підтримувати існуючі. А втрата публічних просторів $\epsilon$ однією із причин «затухання публічного життя» («a decline in public life») та комунікабельності в суспільстві [21]. 3. Ніл пояснює це тим, що публічні простори $є$ місцями для багатьох типів персональної взаємодії («person-to-person interaction»), які $\epsilon$ втіленням публічного життя: громадського, суперечливого, творчого [6].

Архітектор Я. Гейл (Jan Gehl) 3 точки зору соціально-просторовому підходу описує динаміку відкритих публічних просторів на прикладі європейських та американських міст [19]. Він пише, що на вулицях міст початку XX століття завжди можна було спостерігати активне життя, що супроводжувалось здійсненням певного виду людської діяльності. Вулиці, площі, ринки, парки 
- це місця зустрічей, комунікацій, соціалізації, території самовираження. Нині вулиці повні людей, які використовують публічний простір через необхідність, характерні для малорозвинених країн. Для сучасної людини немає необхідності обов'язкового перебування в публічному просторі. Це є їі вибором за бажанням.

На думку Я. Гейла необов'язковий характер більшості заходів публічного життя в сучасних містах визначає високі вимоги до якості пропонованих публічних просторів. Вузькі, розділені тротуари, різні перешкоди, бордюри, складні пішохідні переходи вулиць, паркани, відсутність місць для сидіння, гри і тому подібне роблять публічний простір непривабливим. Чим нижча якість конкретного публічного простору, тим менша його популярність, а отже відвідуваність. Таким чином занедбаність публічного простору стає однією з причин його втрати. Публіка відмовляється використовувати занедбаний, некомфортний, непривітний простір на користь приватного простору, який подібний до публічного. Під якісними публічними просторами Я. Гейл розуміє вдало розташовані із дизайнерським оформленням атрактивні (привітні) простори, які змушують жителів міст частіше залишати їхні заміські будинки $[6,19]$.

Слід зазначити про можливість двох сценарії динаміки для існуючого занедбаного публічного простору залежно від його розташування, про які веде мову 3. Ніл [6]. На його думку, парк, який розташований на околицях міста, де проживає населення 3 низьким рівнем доходів, поступово втрачає відвідувачів i переходить під контроль маргінальних груп (стає місцем проживання безхатьків, територією збуту нелегальних товарів тощо). 3 часом, як правило, його закривають та зносять. Міська влада не здійснює ревіталізацію та повторне відкриття парку в цій місцевості, оскільки це повязане 3 додатковими фінансовими витратами. У той же час, занедбана публічна власність, розташована в районах 3 високою рентною платою (особливо, якщо це великий публічний фонтан, площа, музей), часто стає потенційним об'єктом приватизації. На їх місці в більшості випадків 3 комерційною метою створюють напівпублічні простори («semi-public spaces») - торгові та ресторанні заклади [21]. У цьому випадку також присутне виключення небажаної публіки (запобігання приходу безхатьків, прохачів милостині, «бюджетних» туристів) шляхом встановлення фізичних бар'єрів, камер спостереження, присутності приватної охорони, створення специфічної атмосфери, яка унеможливлює тривале перебування небажаної публіки через відчуття «бути не у свойй тарілці».

М. Лопес та С. Круз (Miguel Lopes, Sara Cruz) у статті «Зміна публічності міських просторів» («Тhе changing publicness of urban spaces») визначили, що приватизація одночасно є як наслідком, так i причиною втрати публічного простору i поширення міської фрагментації [21].
Поряд із переважаючими песимістичними поглядами, Я. Гейл (Jan Gehl) та Л. Гемзо (Lars Gemzoe) [9] звертають увагу на певні позитивні сторони динаміки публічного простору, що проявилися у поверненні традиційних форм публічних просторів міст. Як правило, це відбувається під тиском мешканців міст, які прагнуть задовольнити одну із базових потреб людини - комунікації. Стосується це феномену присвоєння громадянами таких просторів, як фермерські ринки, антикварні ярмарки, кінотеатри під відкритим небом, міських підземних просторів.

Важливим напрямком зарубіжних досліджень публічних просторів є їх просторовий аналіз та планувальні аспекти.

Нові публічні простори плануються за такою формулою: «спочатку будівлі, потім простори, потім (можливо) життя» («first buildings, then spaces, then (perhaps) life») [19]. Результатом використання цього правила при плануванні просторового розвитку міста $€$ нерівномірний розподіл публічних просторів по території міста із значною диференціацією центр-околиці. Як правило, створення нових публічних просторів плануються в інвестиційно найпривабливіших районах, де вже $€$ певна концентрація капіталу. Суттєва різниця у концентрації відкритих публічних просторів міста зумовлює нерівність їх доступності для жителів. Вона проявляється в двох аспектах: у фізичній віддаленості для певних груп людей та у винятковому (ексклюзивному) використанні найближчими заможними мешканцями. Таким чином, окремі території міста стають «пустелями», а публічне життя подекуди переміщується у нові локації. Д. Кріллі (Darrell Crilley) у книзі «Мегаспоруди і міські зміни: естетика, ідеологія та дизайн» («Megastructures and Urban Change: Aesthetics, Ideology and Design») [7] зазначає, що публічне життя за таких умов планується i навмисно створюється у формі театру, має ознаки ретельно зрежисованого спектаклю у місті. Самі ж простори, як зазначають М. Соркін (Michael Sorkin) та Ш. Зукін (Sharon Zukin) створюються як анімаційні («disneyfying» the space»), або, на думку Я. Гейла, як «кишенькові парки» («pocket park»). За таких умов навіть створення нових публічних просторів не гарантує їх втрати [21, 22].

Я. Гейл пропонує використовувати для сучасного міського планування протилежний підхід: спочатку необхідно визначити, яке життя планується на конкретній території, які типи публічних просторів будуть необхідні для нього, а вже потім розмірковувати над тим, які будівлі сформувати на цій території для того, щоб підтримати ці публічні простори. Зрозуміло, що це не може бути єдиним правилом для всього міста. Міські проекти, які реалізуватимуться на землях з високою вартістю, будуть орієнтуватись на задоволення інтересів інвесторів та потреб потенційних споживачів [19].

Ще одним вагомим напрямком зарубіжних досліджень публічних просторів міст $є$ аналіз сучасних їх трансрормацій. 
Нині у містах спостерігається так звана приватизація образу вулиць, площ. У архітектурні стилі вуличних ландшафтів відбувається активна інтервенція приватної реклами. Різні оголошення та постери є скрізь: вздовж доріг, на лавках, смітниках, стовпах, поштових скриньках, телефонних будках тощо. Усі вільні поверхні від тротуарів до фасадів будинків стають рекламними площами. Таким чином, обличчя міста стає прихованим під шаром «рекламної косметики». Якщо раніше публічні простори були одержувачами інвестицій та турботи з боку місцевої влади, то в останнє десятиліття вони перетворились на джерело приватних прибутків шляхом продажу тротуарів для реклами. Площі, які традиційно були публічними просторами, носіями культури i місцями політичних виступів, стають центрами вуличної торгівлі найрізноманітнішими товарами (туристичними сувенірами, «всякою всячиною» тощо). В умовах капіталізму публічний простір стає товаром та інструментом продажу міста $[4,6]$.

К. Уебстер (Chris Webster) у своїй статті «Право власності, публічний простір та міський дизайн» («Property rights, public space and urban design») висловив та аргументував тезу про те, що публічні простори часто змінюються по траєкторії від суто суспільного блага до суто приватного блага 3 ексклюзивним правом використання [18]. Спочатку вони формуються та розвиваються як суто суспільне благо, яке підтримується державою та муніципалітетом. Із ростом популярності кількість відвідувачів в них постійно збільшується, тому такі простори можуть стати об'єктом конкурентного споживання. Потім для контролю кількості відвідувачів організація, яка $€$ розпорядником простору (має зобов'язання утримувати простір), вводить правила, які 6 обмежували його використання. Таким чином конкуренція споживання знижується, а простір стає більш ексклюзивним. Як правило обмеження поступово розширюються, детермінуючи контроль над конкретними групами людей (небажаною публікою), а публічний простір набуває характеру частково або повністю приватного. Приватизація публічних просторів $є$ крайньою формою контролю, що призводить до виключення певної публіки та домінування привілегійованої групи людей. Така динаміка публічного простору повністю відповідає процесу джентрифікації (gentryfication), який у кінцевому результаті, крім соціальних, планувальних наслідків, призводить до підвищення вартості землі в окремих районах міста. Під впливом зазначеного процесу відбуваються пов'язані зміни в моделях використання просторів навіть за умови їх існування як суспільного блага.

Відповіддю прогресуючій (галопуючій) приватизації та комерціалізації публічних просторів $\epsilon$ ïx «одомашнення», «інтимізащія». Традиційно прийняте особистим, «приватним» репрезентують перед незнайомими, тобто роблять публічним. Така тенденція знайшла своє вираження в архітектурі та дизайні вулиць: прозорі вітрини і вікна, що дозволяють слідкувати за особистим життям працівників, елементи домашнього вжитку у зовнішньому дизайні кафе та ресторанів. Усе частіше можна спостерігати, як люди сидять на сходах, тротуарах, клумбах, вживають їжу, танцюють та співають просто на вулиці, що раніше було виключною прерогативою дому або призначених для цього місць.

Однією з найбільш поширених форм приватизації публічних просторів міст, які можна спостерігати, є закриті спільноти («gated communities», «closed condominiums»). Виникнення закритих спільнот $\epsilon$ матеріальним вираженням ефекту клубу в соціальному просторі, тобто бажання заможних людей жити виключно в оточені собі подібних. Такі спільноти можуть формуватись у вже існуючих житлових кварталах у результаті процесу джентрифікації або створюватись як нові проекти. Закриті спільноти часто виглядають як i будьяка інші спільнота мешканців, але вони оточені бар'єрами, які перешкоджають доступ нерезидентам до вулиць, тротуарів, парків та інших зручностей. Іншими словами, не виконуються необхідні умови публічності простору - відкритість та доступність. Хоча закриті спільноти мають ті ж самі характеристики простору як і відкриті, їх функції як публічних просторів спотворені. Імовірні зустрічі 3 незнайомими людьми на тротуарах, які 3 плином часу створюють відчуття спільності і при-належності, в них відбутися не можуть, тому що в закритих спільнотах практично не буває випадкових людей. Використання цих просторів для мистецьких заходів може бути обмеженим відповідно до статуту об'єднання власників будинків. Фактично, члени закритих спільнот беруть участь в ілюзорному публічному житті, яке по своїй формі $\epsilon$ приватним. З. Ніл відмічає, що публічні простори закритих спільнот не можуть бути автентичними [6].

Питання автентичності публічного простору піднімаються зарубіжними дослідниками і стосовно такого їх виду, як ТРЦ (моли), які мають своє тематичне оформлення та унікальні назви. Архітектура, елементи декору та дизайн (наприклад, високі стелі, дизайни інтер'єрів, які імітують міські вулиці, просторі коридори та холи, бутафорні декорації, які відтворюють елементи класичної архітектури, паркові атракціони, скляні стелі, стелі, які імітують небо) створюють в ТРЦ відчуття присутності в міському публічному просторі. Складається враження, що будь-хто може виступити 3 власною промовою або почати малювати на підлозі кольоровою крейдою. Насправді ж приватна охорона в такому випадку може затримати особу i супроводити іiі геть. 3. Ніл відзначає, що без детального аналізу прогулянки по ТРЦ можуть виглядати i сприйматись як публічне життя, але насправді це лише індивідуалізоване споживання в упаковці публічного життя [6].

Варто акцентувати увагу на одній деталі, яка характерна для всіх ТРЦ: у просторих коридорах та холах відсутні місця для сидіння або ж їхня кількість критично мала. Дизайн та інтер'єр ТРЦ навмисно 
розробляється таким чином, щоб мінімізувати тривалість перебування відвідувачів поза безпосередньо комерційною площею (крамничками, кав'ярнями, кафе, ресторанами, фуд-кортами тощо), зробити тривалу комунікацію між людьми не зручною. Тобто, справжньої публічності в ТРЦ не існує, оскільки люди, перебуваючи поруч, можуть один одного не помічати.

Проблема ТРЦ як неавтентичного публічного простору знаходить своє вирішення в нових архітектурно-планувальних рішеннях, спрямованих на «відкриття» молів, як закритих публічних просторів. Пріоритетною $\epsilon$ розроблена сучасна модель збільшення ТРЦ у вертикальній площині, яка замінила попередню модель ТРЦ з мінімальною кількістю стін. ІІІІ сутність полягає у збільшенні кількості наземних та підземних поверхів ТРЦ, а одним із обов'язкових елементів є відкриті галереї, що «впускають місто в мол». Наступним кроком стало поєднання житлової та комерційної функцій в ТРЦ - створення «населених» молів.

C. Лоу (Setha Low) та H. Сміт (Neil Smith) у своїй праці «Публічна політика» («The Politics of Public Space») [13] відзначають, що ряд терористичних актів у різних містах світу викликали зміни політики публічного простору. Так, у США обмежується використання багатьох популярних видів публічних просторів, а ексцентричну публічну поведінку особи можна розглядати як потенційну терористичну загрозу. Такі тенденції послаблюють політичну функцію публічних просторів міст. Цікавою $є$ ще одна думка 3 даного питання: дослідники публічних просторів зазначають, що у міському повсякденному житті відбувається війна всіх проти всіх, основною метою якої є публічний простір.

К. Ворпол (Ken Worpole) та К. Нокс (Catherine Knox) [24] констатують, що публічні простори міст знаходяться не в стані занепаду, а навпаки диверсифікації їх форм. На їх думку, публічний простір має бути гнучким і реагувати на соціальні зміни, а нові форми суспільного життя потребують нових публічних просторів.

Окремим напрямком зарубіжних досліджень публічних просторів міст є постсоціалістичні країни. А. Калюкін (Alexander Kalyukin), Т. Борен (Thomas Borén) та А. Баєрлей (Andrew Byerley) у праці «The second generation of post-socialist change: Gorky Park and public space in Moscow» [11] висловлюють думку про першу та другу генерації постсоціалістичних змін міських публічних просторів. Автори вважають, що перша стадія трансформацій публічних просторів у 1990-2000-их роках відбувалася за відсутності фінансових можливостей у держави, тому домінування приватного, в обхід влади, без дозволів і супроводжувалась низькоякісною комерцією та недотримання стандартів. Друга стадія транс- формацій публічних просторів розпочалася з 2010го року під лозунгами «місто для людей», «місто, придатне для життя». Вони орієнтовані на молодий середній клас, пріоритетами якого є креативність, цивілізованість та модність і передбачають вимоги до візуального дизайну, відсутність незаконних вуличних торговців та інфраструктури розваг. Новий підхід зумовлює виключення певних соціальних груп населення, впровадження нових норм поведінки, селективну толерантність (наприклад, можна пити вино на лужайці, але не можна пити пиво на лавці).

Дослідники публічних просторів міст постсоціалістичних країн також висловлюють думку про «європеїзацію» як один із видів їх трансформацій [11]. Мешканцями міст «європеїзований» міський публічний простір уявляється відкритим, 3 вільним доступом для таких як вони, з потенціалом для взаємодії і спілкування, вільний від контролю репресивних органів. Девелопери сприймають його як вибірковість, елітність, що приваблює лише певну частину громадськості, фактично, як «цивілізований». Варто зазначити, що західним ідеалом публічного простору є диверсифікований (різноманітний) та толерантний публічний простір.

Висновки. Публічні простори міст в Україні інтенсивно змінюються. Вони відновили свої політичні функції i активно використовуються як території політичного протесту, конфлікту пам'ятей. 3 «нічиєї території» публічні простори стають місцями самоорганізації локальних спільнот. Вони відновлюються, реставруються в спальних районах міст. Публічні простори українських міст комерціалізуються, у т.ч. і в контексті відновлення, реставрації, ревіталізації, розвитку туризму, відповіді на потребу та вподобання міських жителів. Для них характерні сакралізація, «диснейфікація» та «б’ютифікація», «європеїзація». Однак, як стверджує I. Тищенко, «намагання швидко скопіювати західноєвропейську чи американську моделі життєустрою знову і знову переконують у неможливості повноцінного втілення цих моделей, оскільки, як свідчить історія, не можна штучно зімітувати процеси, які в західній урбаністичній традиції відбувалися протягом століть» [5]. Отже, публічні простори українських міст потребують досліджень на основі сучасних зарубіжних концептуальних засад 3 метою виявлення як спільних, так і особливих їх рис та процесів порівняно із європейськими та американськими містами.

Що таке ідеальний публічний постір міста? Чи однаковий він у різних суспільствах? Яким він $є$ чи може бути у містах постсоціалістичних країн та в Україні? Над цими питаннями ми будемо розмірковувати в наступних роботах.

\section{References:}

1. Arendt G. Stanoviŝe lûdini: Analìz trìadi pracâ- tvorčist'- dîa (Translation from English). Lviv, 1999, 254 p. (In Ukrainian).

2.Gabermas U. Strukturni peretvorennâ u sferì vidkritostì (Translation from German). Lviv, 2000,318 p. (In Ukrainian). 
3. Džakobs Dž. Smert' i žizn' bol'ših amerikanskih gorodov (Translation from English). Moscow, 2011, 460 p. (In Russian).

4. Mezentsev K., Mezentseva N., Bura T. Public space transformations in big cities of Ukraine on the example of large shopping malls. Ekonomichna ta Sotsialna Geografiya, 2011, Vol. 63, pp. 174-186. (in Ukrainian, abstr. in English).

5. Tiŝenko Ì. Vìd antizabudovnih protestìv do «prava na mìsto»: res publica na Kontraktovìj ploŝì v kontekstì transformaciï mìs'kogo prostoru Kiêva. Mìsto ì onovlennâ. Urbanìstičnì studï [City and Renovation. Urban Studies], 2013, pp. 284-315. (In Ukraine).

6. Common ground? Readings and Reflections on Public Space [Editors: Z. Neal, A. Orum]. New York: Routledge, 2009, 240 p.

7. Crilley Darrell. Megastructures and Urban Change: Aesthetics, Ideology and Design. New Jersey: Prentice Hall, 1993, pp. 127-164.

8. Davis M. The City of Quartz: Excavating the Future of Los Angeles. London: Verso, 1992, 462 p.

9. Gehl Jan. New City Spaces. Copenhagen: The Danish Architectural Press, 2001, 263 p. $187 \mathrm{p}$.

10. Harvey D. Rebel Cities. From Right to the City to the Urban Revolution. London \& New York : Verso, 2012,

11. Kalyukin A., Borén T., Byerley A. The second generation of post-socialist change: Gorky Park and public space in Moscow. Urban Geography, 2015. Vol. 36, No. 5, pp. 674-695.

12. Lefebvre H. Writings on Cities [The Right to the City]. Oxford : Blackwell Publishers, 2000, pp. 147 - 160.

13. Low S., Smith N. The Politics of public space. Taylor \& Francis Group, 2006, pp. 1-17.

14. Lynch K. The image of the city. The MIT Press, 1960, $280 \mathrm{p}$.

15. Madanipour Ali. Public and private spaces of the city. London: Routledge, 2003, 224 p.

16. Mitchell D. The Right to the City: Social Justice and the Fight for Public Space. New York : The Guilford Press, 2003, 270 p.

17. Neal Z. Seeking common ground: three perspectives on public space. Urban Design and Planning. - 2010, pp. $1-8$.

18. Property rights, public space and urban design. The Town planning review, 2007. Access mode: https:/www. researchgate.net/publication/240822211

19. Public spaces for a changing public life. Access mode: https://www.openspace.eca.ed.ac.u

20. Sennett R. The fall of public man. London: Penguin Books, 2002, 373 p.

21. The Changing Publicness of Urban Spaces. Conference Paper, 2013. Access mode: https://www.researchgate. net/profile/Miguel_Lopes11/publication.

22. Variations on a Theme Park: The New American City and the End of Public Space / [Editor: Michael Sorkin]. New York: Hill and Wang, 1992, 251 p.

23. Whyte H. William. The Social Life of Small Urban Spaces. New York: Project for Public Space, 2001,129 p.

24. Worpole K., Knox C. The social value of public spaces. New York: Joseph Rowntree Foundation, 2007,16 p. 